\title{
A Critical Review of the Transport and Health Effects of Persistent Organic Pollutants
}

\author{
Adegun Ayodeji O*, Akinnifesi Thompson A, Ololade, Isaac I \\ Department of Chemical Sciences, AdekunleAjasin University, Akungba Akoko, Nigeria
}

DOI: $10.36348 /$ sijems.2020.v03i05.001

| Received: 27.05.2020 | Accepted: 05.06.2020 | Published: 30.06.2020

*Corresponding author: Adegun Ayodeji O

\section{Abstract}

Persistent organic pollutants (POPs) are toxic chemicals which affect the health of human beings and the environment adversely. These pollutants could be transported by wind and water. They could affect people and animals in other countries far from where they were generated initially. POPs persist in the environment for a long time before they are degraded. They bioaccumulate in organisms through the food chain. These chemicals include the organochlorine pesticides and other halogenated organic compounds such as polychlorinated biphenyls (PCBs) and dioxins.The aim of this review is to examine the transport of these pollutants from their point of application and look into their effects on human health. Recent studies reported the gradual introduction of these banned chemicals under different trade names into the environment. Therefore, this review will re- enlighten the public on the dangers in the transportation as well as the harmful effects of these pollutants as they also biomagnify in human. Proper measures on the handling, usage and regulation of these contaminants especially the synthentic organochlorine pesticides should be rekindled worldwide.

Keywords: persistent organic pollutants, bio-accumulate, bio-magnify, toxic, environment; health

Copyright @ 2020: This is an open-access article distributed under the terms of the Creative Commons Attribution license which permits unrestricted use, distribution, and reproduction in any medium for non-commercial use (NonCommercial, or CC-BY-NC) provided the original author and source are credited.

\section{INTRODUCTION}

Toxic compounds are made of organic and inorganic substances [1].These compounds include organochlorine pesticides, polychlorinated Biphenyls (PCBs), and poly aromatic Hydrocarbons (PAH) and fire retardants $[2,3]$. Inorganic toxic chemicals such as lead, mercury, zinc, cadmium, acids and salts are also included in toxic compounds classification. These chemicals have severe effect on the ecosystem and water bodies [4].They could be threat to human and aquatic systems and resist environmental breakdown [5]. They are not easily degradable and they persist in the environment for a long time [6-11].

Agrochemicals such as organochlorine pesticides contaminate drinking water. Their effect is a great concern as they affect the water systems and aquatic lives [12-14]. Pollution of water by agricultural chemicals adversely affects the fish and wildlife [15]. Generally, bacteria and viruses found in water cause diseases in human public drinking water supplies. However, pollution by sythentic organic pollutants is of global concern due to their toxicity and persistence [16].
Runoff from minning operations could also be a source of water pollution as the exposed rocks during the mininig operation create acidic runoff. This acidic runoff could seep into neaby water bodies and changes aquatic environment $\mathrm{pH}$ [17].

Organic chemicals such as asphalt used for road constructions could also pollute water systems. When water, is in contact with these surfaces, they could runoff and be absorbed into the surrounding environment. Their presence in water could be harmful to aquatic eco system. Chemicals used for the care of lawns could also enter into the environment through runoff or other sources. Moreover, chemicals that are used for the maintenance of boats could also leak into the water thereby contaminating it [17].

The most toxic of these pollutants to man are the persistent organic pollutants(POPs) which cause different health issues such as cancer, birth defects, developmental defects, diabetes, seizures ,convulsions and possibly death. Therefore, this review aimed at creating awareness to the public on the dangers of these pollutants in the environment. Recent published work on these contaminants revealed that they are still present in the environment. Farming, contributed to this 
menace as farmers continue to use these banned chemicals especially in developing countries to control pests affecting their crops in order to increase their yield. The organochlorine agrochemicals are highly potent for the control and killing of pests thus their demand for agricultural activities have increased in developing nations. Although, these chemicals have been banned globally, farmers in developing nations are still buying them under different trade names. Thus, the general objective of this review is to examine the transport route of exposure to these pollutants and their human health effects.

\section{Persistent Organic Pollutants}

Persistent organic pollutants (POPs) are organic pollutants that are very toxic, stable and persist for long period with adverse effect on human and the environment. They could also accumulate in aquatic lives [2, 4, 6-7]. POPs are of great concern and a treaty was signed in Stocholm, Sweden on May 2001 on the eradication of these initial 12 POPs known as "dirty dozen" [18]. Twelve initially banned POPs are aldrin, chlordane, dichlorodiphenyl trichloroethane (DDT), dieldrin, endrine, heptachlor, hexachlorobenzene, mirextoxaphane, polychlorinatedbiphenyls (PCBs), dibenzodioxin (Dioxins), polychlorinated dibenzofurans (furans). Chlordecone, hexacyclochlorohexane, hexabromodiphenylether, pentachlorobenzene, perchlorooctasulphuricacid, endosulfans, and hexabromocyclododecane were the additionally banned POPs known as the nasty nine [19, 20]. Chemicals intentionally produced are used currently for the control of agricultural disease. Additionally, industrial processes are made of POPs as active ingredients [19]. POPs such as dioxin, can also be produced unintentionally in the environment. These could result from industrial processes and combustion. Municipal and medical wastes incineration as well as burning of trash could also lead to the production of these pollutants [5]. Majority of these POPs, were used as pesticides in the past. They were also used as solvents, pharmaceuticals and industrial chemicals. Some POPs such as volcanoes and biosynthetic pathway occurs naturally [9].

\section{Transport of persistent organic pollutants}

POPs are halogenated organic compounds with high fat solubility. Therefore, they bio accumulate in lipid tissues and exert negative effects on the environment. Through the process of long range transport [10-15]. This transportation route allows them to travel far from their source and re-concentrate into potentially dangerous pollutants [21, 22].The long range transport of POPs involve their entering into the gas phase (Figure1) [23]. They can also volatilize from soils, vegetation or water bodies into the atmosphere[22-23].They resist degradation and also travel long distances before being deposited[24].These pollutants deposition results in their accumulation in areas far from where they were used initially .emitted or produced [21-22, 25]. They could also be found in environments where they have never been used before [26]. They move up the food chain and bioaccumnulate in diet [9-15]. Their level increase as they are processed and metabolized in certain tissues of organisms [27-28]. A positive relationship exists between low level exposure of these contaminants and various diseases of man [29]. Human health risk assessment may be produced by government agencies which will take into account the pollutants bioavailability and dose response [27-28]. Several studies have been carried out globally on POPs especially OCPs and PCBs level [30-31]. Pollution studies outcome of environmental and biological matrices reveal that these contaminants are still present in the environment [23].

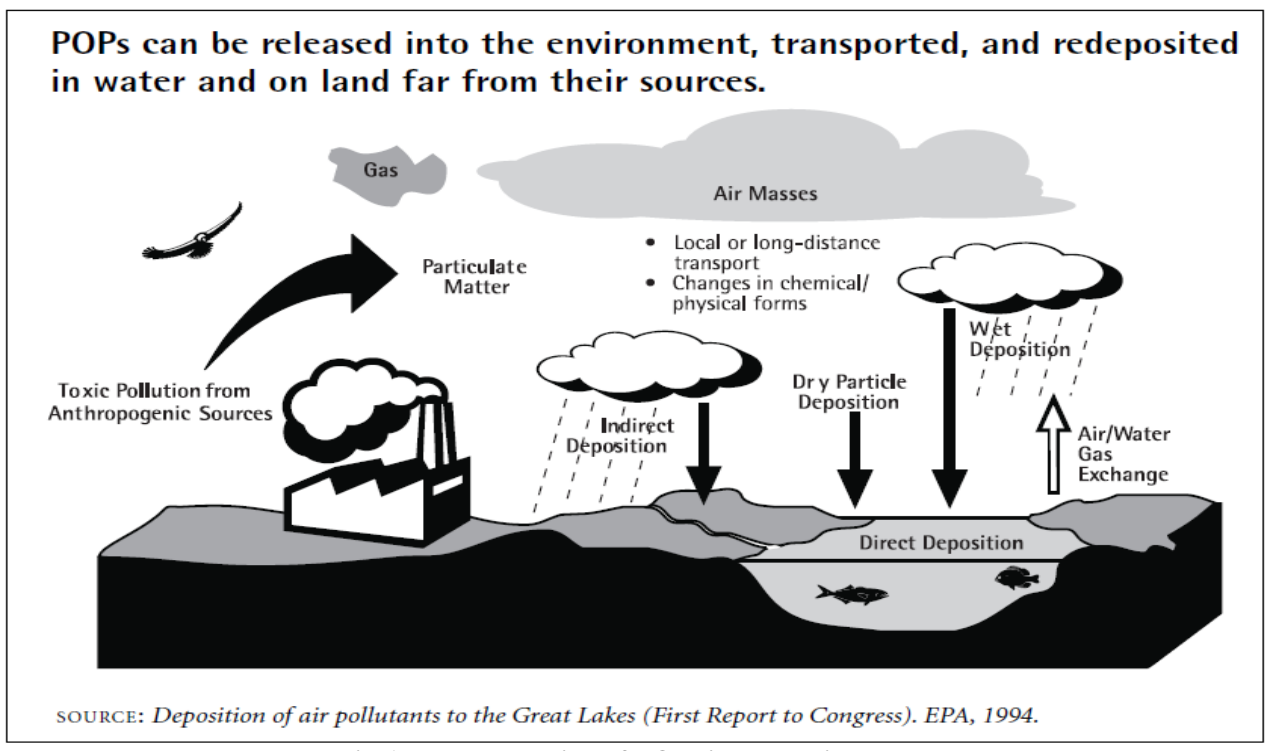

Fig-1: Transportation of POPs in the environment 


\section{Types of persistentpersistent organic pollutants} (pops) dirty dozens

Table1 contains the twelve POPs banned at the Stocholm convention known as dirty dozens. This dirty dozens include: aldrin, chlordane, dichlorodiphenyltrichloroethane (DDT), dieldrin, endrine, heptachlor, mirex and toxaphanehexachlorobenzene, polychlorinated biphenyls (PCBs) and, polychlorinated dibenzo dioxins (Dioxins), polychlorinated dibenzofurans (furans) (Figure) [4]. Surprisingly, Some of these banned POPs are organo chlorine pesticides while the others are heavy chemicals and unintentional by products [56].The organochlorine pesticides among the twelve dirty dozen are aldrin, chlordane, dichlorodiphenyltrichloroethane (DDT), dieldrin, endrine, heptachlor, mirex and toxaphane hexaldrin, chlordane, dichlorodiphenyltrichloroethane (DDT), dieldrin, endrine, heptachlor, mirex and toxaphane hexa chlorobenzene while the others are industrial chemicals and unintentional by-products.

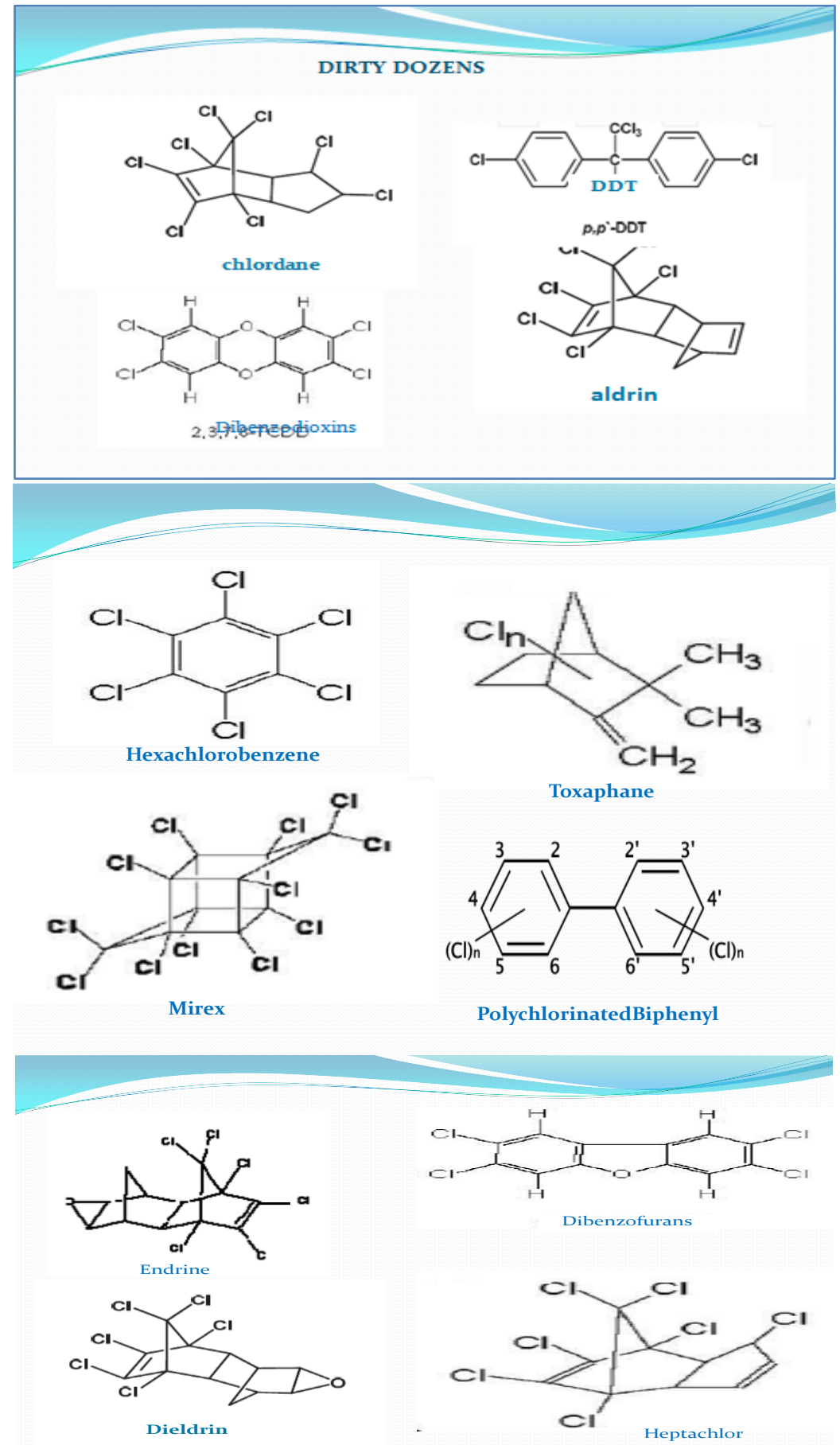

Fig-2: Structures of Dirty dozens 


\section{Organochlorine Pesticides}

Organochlorine pesticides (OCP) are organic chemicals made by man to control insect pests. They were phrased out due to their toxic and persistenct nature [32]. Health effects such as cancer in humans and ecosystem are also of concern from exposure to these halogenated chemicals $[2,9,10,14]$.They were produced originally to protect crops, livestocks, buildings and households from insects which cause damage to them. However, due to their high insectidal potency, in pest's control, they were tremendously used over the years in agriculture. They were banned at the Stockholm convention [3-6, 16-20].OCPs have been used in many commercial products under a wide range of trade names[20].

Organochlorine pesticide contamination of the environment has been been a major concern and threat to human and ecosystem [16, 18]. When pesticides reaches the soil after application. Its residues affect the soil quality by disturbing soil organisms and decomposers [9-12]. This action decreases microbial biomass of the soil and affecting the ecosystem [13-14]. Pesticide residues in soils cause toxicity to plants, and their products thereby contaminating the food chain [22]

These pollutants get into the aquatic environment through effluent release, domestic sewage and industrial waste water discharges, agricultural fields runoff, leaching, equipment washing, disposals of empty containers dumping of wastes into water system and atmospheric deposition [23]. Ecological impacts in water contamination is by pesticide is based on bioaccumulation and biomagnifications. In bioaccumulation, pesticide residues enter into the water and moves into an organism from a surrounding medium where they are metabolized and excreted [1415].

Biomanification involves the transformation of food energy within the food chain as smaller organisms are eaten by larger organisms [32-33]. The concentrations of pesticides and other chemicals are increasingly magnified in the tissue and other organs. High concentrations of these pollutants could be observed in top predators including man [33].

\section{Poly Chlorinate Biphenyl (PCBs)}

PCBs are synthetic organic with 209 distinct congeners [23].They are stable and commonly used in capacitors and other electrical equipment. They have low insulating and boiling capacity [16, 18-19] are classified as possible carcinogen by International Agency for research on cancer [33]. They were specifically produced as specific mixture of cogeners known as arochlors[33].They appear in natural environment due to unintentional and irresponsible human activities[im gime. They could also be released into the environment when wastes containing PCBs are incinerated or stored in landfill (WHO 2000,CDC 2000).Their possible impact on human health and environment made these chemicals to be banned or restricted in many countries [34]. They do not degrade easily and they are resistant to degradation by acids, bases, oxidation, hydrolysis and changes in temperature [23] PCBs could generate extremely toxic dibenzodioxins and dibenzofurans during incineration [23].They penetrate the skin, latex rubber [31]. Studies have shown that environmental matrices have been contaminated with PCBs [23].Studies have also shown that biological species bioaccumulate PCBs from eating fish and other contaminated aquatic animals [23] [30].

\section{Dichlorodiphenyl Trichloro Ethane (DDT)}

DDT was initially used in the second half of world war II to control malaria and typhus among civilians and the troops and after the world war it was used as an agricultural insecticide [4-6][19]. DDT is one of the "12 dirty dozen" banned globally at the Stocholm convention in 2001[16, 18-19]. Despite its ban,it is still being used for disease control in some developing countries[4-5]. The major metabolites of DDT are DDD and DDE [35]. DDT bioaccumulates in fatty tissue because of their lipophilicity [36]. DDT and its metabolites magnify through the food chain. The apex predators such as birds concentrate more of the chemicals than the other animals in the same environment [37]. DDT and its metabolites are resistant to metabolism in humans $[13,24]$. The half-life of this compound is 6 to 10 years $[26,36]$.

\section{Polychlorinated Dibenzon Dioxins}

Dioxins are unintention industrial by products processes that are toxic and persistent in the environment [18, 19].The half-life of Polychlorinated Dibenzon Dioxins is 7-11 years [2, 18-19].The most important source of human exposure of dioxin is through fatty food of animal origin [2] and breast milk [3].

\section{Polychlorinated Dibenzon Furans}

Polychlorinated dibenzofurans are POPs compounds with one or several hydrogen in the diebenzo furans structure replaced by chlorine atoms. Dibenzofurans are much more toxic than their parent compound and their properties and structure are similar to dibenzodioxins[3-6].They are also classified among the "dirty dozen [16]. 
Table-1: Route of Exposure and Some Human Health Effects of Dirty Dozens

\begin{tabular}{|c|c|c|c|c|}
\hline POPs & $\begin{array}{l}\text { Classification of } \\
\text { POPs }\end{array}$ & Exposure Route & Acute and chronic human health effects & References \\
\hline Aldrin & $\begin{array}{l}\text { organochlorine } \\
\text { pesticides }\end{array}$ & $\begin{array}{l}\text { Ingestion inhalation, } \\
\text { Skin }\end{array}$ & Cancer & [34-35] \\
\hline Chlordane & $\begin{array}{l}\text { Organochlorine } \\
\text { Pesticides }\end{array}$ & $\begin{array}{l}\text { Ingestion } \\
\text { Inhalation } \\
\text { Skin }\end{array}$ & $\begin{array}{l}\text { testicular cancer } \\
\text { changes in their liver function, respiratory } \\
\text { infections, immune system activation, } \\
\text { anxiety, depression ,blurry vision }\end{array}$ & $\begin{array}{l}{[16][18]} \\
{[34][35]}\end{array}$ \\
\hline Dieldrin & $\begin{array}{l}\text { Organochlorine } \\
\text { Pesticides }\end{array}$ & $\begin{array}{l}\text { Ingestion } \\
\text { Inhalation } \\
\text { Skin }\end{array}$ & $\begin{array}{l}\text { endocrine disruption.testicular descent, } \\
\text { Parkinson breast cancer, immune and } \\
\text { reproductive system damage }\end{array}$ & {$[35,38]$} \\
\hline Endrin & $\begin{array}{l}\text { Organochlorine } \\
\text { Pesticides }\end{array}$ & $\begin{array}{l}\text { inhalation, ingestion } \\
\text { and skin }\end{array}$ & $\begin{array}{l}\text { Culvulsion, the central nervous system } \\
\text { disorder; }\end{array}$ & {$[34,35,38]$} \\
\hline Heptachlor & $\begin{array}{l}\text { organochlorine } \\
\text { pesticides }\end{array}$ & $\begin{array}{c}\text { Ingestion } \\
\text { (drinking water and } \\
\text { food and breast milk) } \\
\text { decrease }\end{array}$ & Type 11 diabetes & {$[34,38]$} \\
\hline Hexachlorobenzene & $\begin{array}{l}\text { Organochlorine } \\
\text { pesticides } \\
\text { (fungicides) }\end{array}$ & $\begin{array}{l}\text { Ingestion } \\
\text { Inhalation } \\
\text { Skin }\end{array}$ & $\begin{array}{l}\text { liver diseases, skin lesion with } \\
\text { discolouration, ulceration, hotosensivity, } \\
\text { bone and thyroid effects }\end{array}$ & {$[34,35,38]$} \\
\hline Mirex & $\begin{array}{l}\text { Organochlorine } \\
\text { pesticides }\end{array}$ & $\begin{array}{l}\text { Ingestion } \\
\text { Inhalation } \\
\text { Skin }\end{array}$ & $\begin{array}{l}\text { liver problems, endocrine disruption and } \\
\text { cancer }\end{array}$ & {$[34,35]$} \\
\hline Toxaphane & $\begin{array}{l}\text { Organochlorine } \\
\text { pesticides }\end{array}$ & $\begin{array}{l}\text { Ingestion } \\
\text { Inhalation } \\
\text { Skin }\end{array}$ & tyroid, liver and kidney & {$[34,35]$} \\
\hline $\begin{array}{l}\text { Polychlorinated } \\
\text { Biphenyl }\end{array}$ & Industrial chemicals & $\begin{array}{l}\text { mainly } \\
\text { by } \\
\text { ingestion } \\
\text { (food) }\end{array}$ & $\begin{array}{l}\text { Skin damage } \\
\text { (chlorance) } \\
\text { liver damage, immune compromise and } \\
\text { motor control problems }\end{array}$ & {$[27,34,35]$} \\
\hline $\begin{array}{l}\text { Dichlorodiphenyl } \\
\text { Trichloro Ethane (DDT) }\end{array}$ & $\begin{array}{l}\text { Organochlorine } \\
\text { pesticides }\end{array}$ & $\begin{array}{l}\text { Ingestion } \\
\text { Inhalation } \\
\text { Skin }\end{array}$ & $\begin{array}{l}\text { endocrine disrupting } \\
\text { carcinogenic disruption in human semen } \\
\text { quality menstruating gestational length and } \\
\text { duration of lactation thyroid function in } \\
\text { pregnancy and childhood }\end{array}$ & $\begin{array}{l}{[27,34,35,} \\
38]\end{array}$ \\
\hline $\begin{array}{l}\text { Polychlorinated } \\
\text { Dibenzon Dioxins }\end{array}$ & $\begin{array}{l}\text { Unintentional } \\
\text { by-products }\end{array}$ & $\begin{array}{l}\text { Ingestion } \\
\text { nhalation skin }\end{array}$ & $\begin{array}{l}\text { Reproductive, developmental and immune } \\
\text { system interference and cancer risks, skin } \\
\text { disease (chlorance) liverdamage, } \\
\text { metaboismalterations, serum lipid level } \\
\text { alterations, alteration of thyroid function, } \\
\text { diabetes and immocological effects } \\
\text { sperm count and motilitydamage }\end{array}$ & {$[35,38-39]$} \\
\hline $\begin{array}{l}\text { Polychlorinated } \\
\text { Dibenzon Furans }\end{array}$ & $\begin{array}{l}\text { Unintentional by- } \\
\text { products }\end{array}$ & $\begin{array}{l}\text { Ingestion } \\
\text { inhalation skin }\end{array}$ & carcinogenic,mutagenenic and tetragenic & {$[2,34,35]$} \\
\hline
\end{tabular}

\section{Nasty Nine}

The additionally banned POPs are referred to as nasty nineas shown in Figure 3 include: chlordecone, Hexabromodiphenyether, lindane, pentachlorobenzene, pentabromodiphenylether, alpha hexachlorocycloexane, betahexachlorocyclohexane, perchlorooctasulphuric acid (PFOS), endosulfans, and hexabromocyclododecane[20]

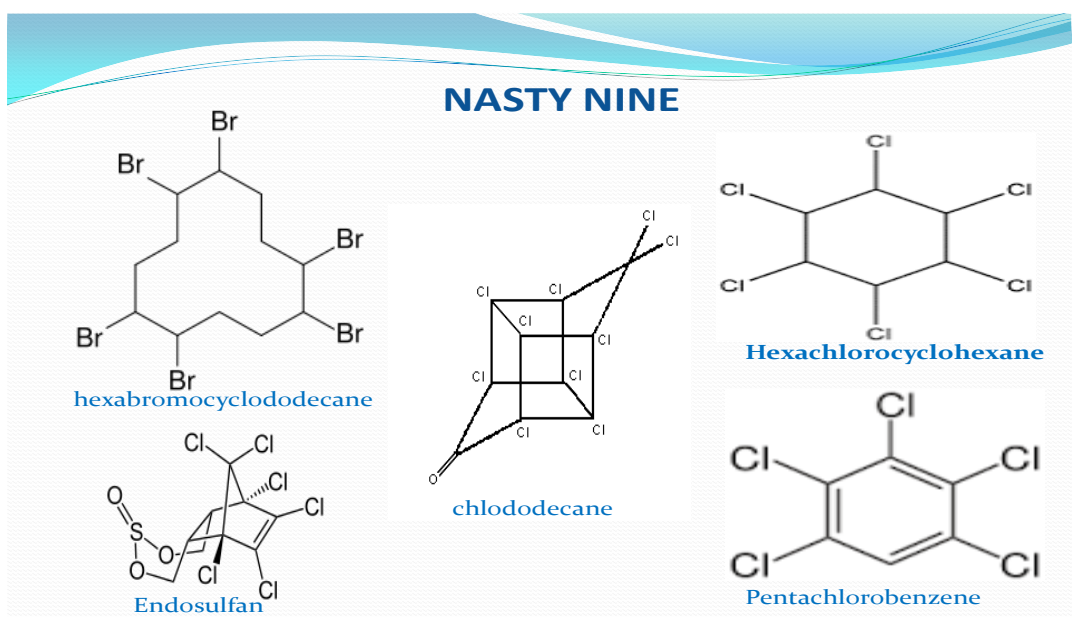




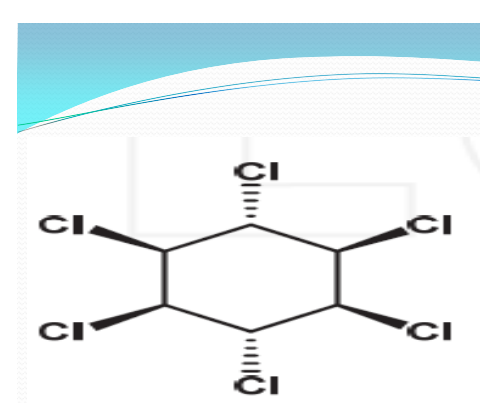

lindane

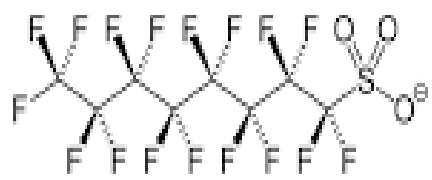

Perchlorooctanesulfonic acid<smiles>Cc1ccc(Oc2cc(Cl)c(Cl)cc2Cl)cc1C</smiles>

Pentachlorodiphenylether<smiles>Brc1cc(Br)c(Br)c(Oc2ccc(Br)c(Br)c2Br)c1</smiles>

Hexabromdiphenyl ether

Fig-3: Structures of the Nasty Nine

\section{Types of Nasty Nine Chlodecone}

Chlordecone also known as keponeis a known

POP and banned globally by the Stolcholm.convention.Chlodecone was included in 2009 banned chemicals known as nasty nine. They also persist in the environment and are harmful to the environment and human [18].

\section{Alpha Hexachlorocyclohexane \\ Alpha hexacchlorocyclohexane is an} organochlorine which is a by-product of an insecticide called lindane.It bioaccumulates and biomagnify in environmental and biota matrices[16].

\section{Hexabromodiphenylether}

They are halogenated compounds usually used as flame retardant [40]. They have been used in a wide variety of products. They are also used for building materials, electronics manufacturing and furnishings. They are also used in the making of motor vehicles, airplanes; plastics and polyurethane.They are similar to PCBs and other poly halogenated compounds which consist of two halogenated aromatic compounds [41]. Hexa bromodiphenylether consist of 209 cogeners [42]. The commercially available PBDE products are not simple compounds and no single congeners but rather a mixture of cogeners. The lower brominated PDEs with 1-5 bromine atoms per molecule are regarded more dangerous because they bioaccumulate[25].

\section{Lindane}

Lindane was originally being used as agricultural insecticide and as a pharmaceutical compound for treating for lice and scabies [8].The production and agricultural use of lindane was banned under the Stocholm convention on persistent organic pollutants [2-6]. Lindane is persistent and transported long distances. It can bioaccumulates in food
chain[18].It is broken down in soil ,sediments and water into less harmful substances by algae, fungi and bacteria[43].The alpha and beta isomers of lindane are more toxic than lindane but do not have insecticidal properties[43]. Lindane is classified by WHO as a moderately harzadous [44]. It is restricted and regulated under the Rotterdam Convention [20].

\section{Pentachlorobenzane (PeCB)}

Pentachlorobenzane is a chlorinated aromatic hydrocarbon [20]. It is an intermediate in the manufacture of pesticides especially fungicides. It is also used as fire retardants. It was added to chemical compounds covered by the Stocholm convention [45]. It is toxic in aquatic organisms [20]. It persists in the environment [3-6]. They are also used as flame retardants [45].

\section{Perfluorooctanesulfonic Acid (PFOS)}

PFOS is a fluorosurfactant that lowers the surface tension of water. It is a dominant commercial mixture and harmful to human and the environment [4$8]$. They are toxic, persistent and they bioaccumulate in mammalian specie [46-47].

\section{Endosulfan}

Endosulfan is a is a $\mathrm{n}$ agrochemical with acute toxicity and bioaccumulation potential and role as an endocrine disruptor and threats to human health and the environment, it was banned globally under the Stocholm Convention [20].

It is used to control pests but it has negative effect on the populations of some beneficial insects [48]. It is considered to be moderately toxic to honey bees [20]. Its chemical properties are similar to aldrin, chlordane and heptachlor [48]. It is one of the most toxic pesticides [20]. It is responsible for many fatal pesticide poisoining and at low dosage; it can cause death [44]. 


\section{Hexabromododecane (HBCD)}

Hexabromocyclododecane (HBCD), is a brominated flame retardants [49]. It is used as thermal insulators in building, automobile, and furniture [18]. It is also used in making packaging materials, videocassette, housing recorder, as well as electrical equipment [20]. It is toxic and found in environmental samples [20]. It could be found in in biological systems and aquatic organisms [49]. It is also persistent, bioaccumulative and undergoes long range transportation $[3,9]$.

\section{Bioaccumulation of pops}

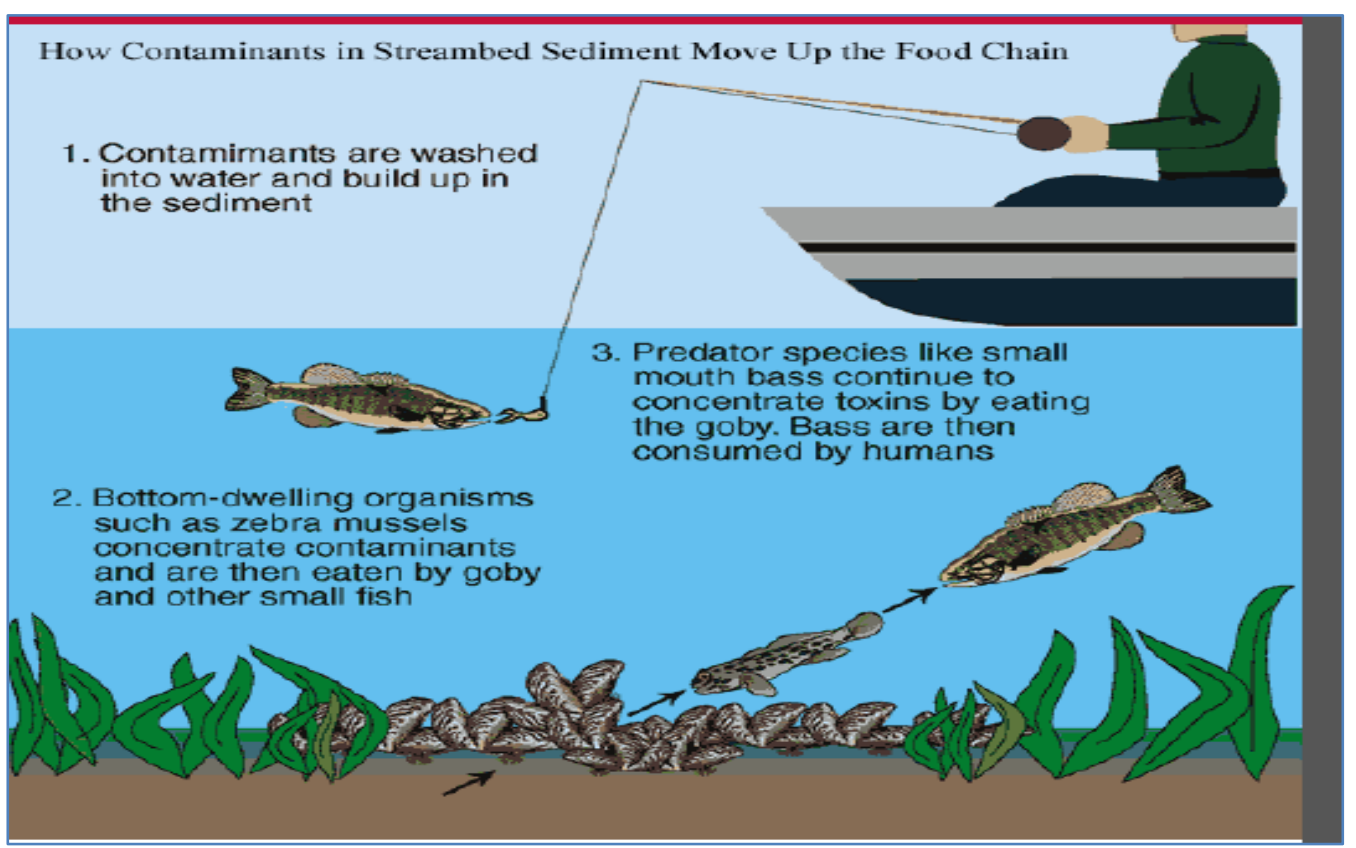

Fig-4: POPs contaminants bioaccumulation

Source: Pests, Pesticides, Pesticide Risks \& USAID’s Response. Visit www.encapafrica.org

Table-2: Route of exposure and human health effects of the nasty nine

\begin{tabular}{|l|l|l|l|l|}
\hline $\begin{array}{l}\text { Persistent organic } \\
\text { pollutants }\end{array}$ & $\begin{array}{l}\text { Classification of Persistent } \\
\text { organic pollutants }\end{array}$ & $\begin{array}{l}\text { Route } \\
\text { of exposure }\end{array}$ & $\begin{array}{l}\text { Acute and chronic human } \\
\text { health effects }\end{array}$ & References \\
\hline Chlodecone & OrganochlorinePesticides & $\begin{array}{l}\text { Ingestion } \\
\text { inhalation, } \\
\text { skin }\end{array}$ & $\begin{array}{l}\text { Severe convulsions } \\
\text { resulting from degradation } \\
\text { of synaptic junctions }\end{array}$ & {$[49]$} \\
\hline $\begin{array}{l}\text { Alpha Hexachloro } \\
\text { Cyclohexane }\end{array}$ & $\begin{array}{l}\text { Organochlorine } \\
\text { Pesticides (by-product of } \\
\text { lindane) }\end{array}$ & $\begin{array}{l}\text { Ingestion } \\
\text { inhalation, } \\
\text { skin }\end{array}$ & $\begin{array}{l}\text { Altered } \\
\text { hormone,poor } \\
\text { development }\end{array}$ & {$[50]$} \\
\hline $\begin{array}{l}\text { Hexabromoin } \\
\text { ether }\end{array}$ & flame retardants & $\begin{array}{l}\text { Ingestion } \\
\text { inhalation, } \\
\text { skin }\end{array}$ & $\begin{array}{l}\text { reproductive (infertility)and } \\
\text { neurological problems } \\
\text { mental and physical } \\
\text { development disorder }\end{array}$ & $\begin{array}{l}{[41]} \\
{[44]} \\
{[51]}\end{array}$ \\
\hline Lindane & $\begin{array}{l}\text { Organochlorine } \\
\text { Pesticides }\end{array}$ & $\begin{array}{l}\text { Ingestion } \\
\text { inhalation, } \\
\text { skin }\end{array}$ & $\begin{array}{l}\text { skin irritation, seizures } \\
\text { burning sensations itching } \\
\text { dryness and rashes nervous } \\
\text { carcinogenic system,liver } \\
\text { and kidneys }\end{array}$ & $\begin{array}{l}{[9]} \\
{[34]} \\
{[38]}\end{array}$ \\
\hline $\begin{array}{l}\text { Beta } \\
\text { Hexachlorocyclohexan } \\
\text { hoor brain development } \\
\text { damage }\end{array}$ & $\begin{array}{l}\text { Organmune system } \\
\text { Pesticides }\end{array}$ & $\begin{array}{l}\text { Ingestion } \\
\text { inhalation, } \\
\text { skin }\end{array}$ & {$[35$} \\
\hline Pentachlorobenzane & $\begin{array}{l}\text { chlorinated aromatic } \\
\text { hydrocarbons }\end{array}$ & $\begin{array}{l}\text { Ingestion } \\
\text { inhalation, } \\
\text { skin }\end{array}$ & & {$[51]$} \\
\hline
\end{tabular}




\begin{tabular}{|l|l|l|l|l|}
\hline $\begin{array}{l}\text { Perfluorooctanesulfonic } \\
\text { Acid } \\
\text { PFOS) }\end{array}$ & $\begin{array}{l}\text { anthropogenic fluoro } \\
\text { surfactant }\end{array}$ & $\begin{array}{l}\text { Ingestion } \\
\text { inhalation, } \\
\text { skin }\end{array}$ & $\begin{array}{l}\text { immune system } \\
\text { cancer, stunted growth, } \\
\text { Preeclampsia in pregnant } \\
\text { women. Thyroid hormone } \\
\text { disorder }\end{array}$ & $\begin{array}{l}{[27]} \\
{[34]} \\
{[46]}\end{array}$ \\
\hline Endosulfan & $\begin{array}{l}\text { Organochlorine } \\
\text { Pesticides }\end{array}$ & $\begin{array}{l}\text { Ingestion } \\
\text { inhalation, } \\
\text { skin }\end{array}$ & $\begin{array}{l}\text { Development defects as } \\
\text { sexual maturity delay in } \\
\text { boys and sex hormones } \\
\text { interference. endocrine } \\
\text { distruptor death in humans }\end{array}$ & $\begin{array}{l}{[34]} \\
{[44]} \\
\text { liver and brain damage }\end{array}$ \\
\hline Hexabromododecane & flame retardants & $\begin{array}{l}\text { Ingestion } \\
\text { inhalation, } \\
\text { skin }\end{array}$ & {$[54]$} & \\
\hline
\end{tabular}

\section{CONCLUSION}

Several studies on POPs showed that they are still present in the environment despite their ban. Organochlorine pesticide residues have continued to be detected in environmental and biological matrices till date. This could be attributed to their continuous production, under different trade names. Their transport in the environment as described in this article are also of great concern since they are very persistent. Some of these POPs affect people and environment in areas where they are not applied. They could also pass through international boundaries. Therefore, proper measures should be taken towards exposure to these pollutants in order to avert the possible health effects revealed by this article.

Author's contributions: The authors contributed equally to this study. All the authors read and revised the final manuscript.

Competing interests: The authors declare that they have no competing interests.

\section{REFERENCES}

1. Azmi, M. A., \& Naqvi, S. N. H. (2011). Pesticide pollution, resistance and health hazards. PesticidesThe Impacts of Pesticides Exposure, 26.

2. El-Shahawi, M. S., Hamza, A., Bashammakh, A. S., \& Al-Saggaf, W. T. (2010). An overview on the accumulation, distribution, transformations, toxicity and analytical methods for the monitoring of persistent organic pollutants. Talanta, 80(5), 1587-1597.

3. Szabo, D. T., \& Loccisano, A. E. (2012). POPs and human health risk assessment. Dioxins and Health; John Wiley \& Sons, Inc.: Hoboken, NJ, USA, 4141, 579-618.

4. UNEP-United Nations Environment Program. (2003). Proceedings of the UNEP Workshop to Develop a Global POPs Monitoring Programme to Support the Effectiveness Evaluation of the Stockholm Convention, 24-27 March 2003.

5. Ritter, L., Solomon, K.R., Forget, J., Stemeroff, M., O'Leary, C. (2007). "Persistent organic pollutants" (PDF). United Nations Environment
Programme. Archived from the original (PDF) on 2007-09-26. Retrieved 2007-09-16.

6. Vizcaino, E., Grimalt, J. O., Fernández-Somoano, A., \& Tardon, A. (2014). Transport of persistent organic pollutants across the human placenta. Environment international, 65, 107-115.

7. Witczak, A., \& Abdel-Gawad, H. (2012). Comparison of organochlorine pesticides and polychlorinated biphenyls residues in vegetables, grain and soil from organic and conventional farming in Poland. Journal of Environmental Science and Health, Part B, 47(4), 343-354.

8. Damstra, T. (2002). Potential effects of certain persistent organic pollutants and endocrine disrupting chemicals on the health of children.Journal of Toxicology: Clinical Toxicology, 40(4), 457-465.

9. Lohmanna, R., Breivikb, K., Dachsd, J., Muire, D. (2007). Global fate of POPs: Current and future research directions, 150, 150-165.

10. Rigotto, R. M., Silva, A. M. C. D., Ferreira, M. J. M., Rosa, I. F., \& Aguiar, A. C. P. (2013). Trends of chronic health effects associated to pesticide use in fruit farming regions in the state of Ceará, Brazil. Revista Brasileira de Epidemiologia, 16, 763-773.

11. Zhang, C., Pan, Z., Bai, A, Lij, Lix. (2014). Distribution of Bioaccumulation of Organochlorine Pesticides in Food Web of Nansin lake, China. Environ mon.J Asses. 186 4, 2039-2051

12. Muralidharan, S., Dhananjayan, V., Jayanthi P. (2009)." Organochlorinepesticides in commercial marine fishes of Comboimbatore India and their suitability for human consumption. Environ Res 109:15-21.

13. Teklit, G.A. (2016). "Residual Analysis of Organochlorine pesticides in fish, sediments and water samples from Tekeze Dam,Tigray Ethiopia" J. Environ. Anal Toxicology ,6.342

14. Kafilzadeh, F., Shiva, A. H., Malekpour, R., Azad, H. N. (2012). Determination of organochlorine pesticide residues in water, sediments and fish from Lake Parishan, Iran. W J Fish Mar Sci, 4, 150-154.

15. Shu Rui Cai, Kuo Sun, ShuYing Dong, Yan Mei Wang, ShuaiWang Li Jia. (2014) '’Assessment of Organochlorine Pesticide Residues in Water, 
Sediment, and Fish of the Songhua River', China Journal Environmental Forensics, 15, (4).

16. UNEP. (2001). Final act of the conference of plenipotentiaries on the Stockholm convention on persistent organic pollutants. United Nations Environment Programme, Geneva, Switzerland, 44.

17. National Oceanic and Atmospheric Administration (NOAA). (1998). Sampling and analytical methods of the national status and trend program, Mussel watch projects: 1993-1996 update. NOAA, Silver Spring, MD http://www.nws.noaa.gov/om/cold/

18. United Nations Environment Programme. (2005). Ridding The World Of Pops: A Guide To The Stockholm Convention On Persistent OrganicPollutants" (Pdf). Retrieved on February 2017.

19. "The Dirty Dozen".(2018). United Nations Industrial Development Organization. (UNIDO) Retrieved 27 March 2014"Stockholm Convention On Persistent Organic Pollutants"(PDF). 1-43. Retrieved 27 March 2018.

20. Adding the Nasty nine to the dirty dozens. http//www.dailygreen.com

21. Bao, L. J., Maruya, K. A., Snyder, S. A., \& Zeng, E. Y. (2012). China's water pollution by persistent organic pollutants. Environmental Pollution, 163, 100-108

22. Beyer, A., Mackay, D., Matthies, M., Wania, F., \& Webster, E. (2000). Assessing long-range transport potential of persistent organic pollutants. Environmental Science \& Technology, 34(4), 699-703.

23. Muir, D., \& Sverko, E. (2006). Analytical methods for PCBs and organochlorine pesticides in environmental monitoring and surveillance: a critical appraisal. Analytical and bioanalytical chemistry, 386(4), 769-789.

24. Rashed, M.N. (2013). Organic pollutants Monitoring, risk and treatment. Intech. London. Chapter 7 - Adsorption techniques for the removal of persistent organic pollutants from water and wastewater.

25. Kelly, B.C., Ikonomou, M.G., Blair, J.D., Morin, A.E., Gobas, F.A.P.C. (2007). Food Web-Specific Biomagnification of Persistent Organic Pollutants. Science. 317, 236-239.

26. Mochungong, P., \& Zhu, J. (2015). DDTs, PCBs and PBDEs contamination in Africa, Latin America and south-southeast Asia-a review.

27. Vafeiadi, M., Vrijheid, M., Fthenou, E., Chalkiadaki, G., Rantakokko, P., Kiviranta, H., ... \& Kogevinas, M. (2014). Persistent organic pollutants exposure during pregnancy, maternal gestational weight gain, and birth outcomes in the mother-child cohort in Crete, Greece (RHEA study). Environment international, 64, 116-123.

28. Yu, G. W., Laseter, J., \& Mylander, C. (2011). Persistent organic pollutants in serum and several different fat compartments in humans. Journal of environmental and public health, 2011.
29. Eqani, S. A. M. A. S., Malik, R. N., Alamdar, A., \& Faheem, H. (2012). Status of organochlorine contaminants in the different environmental compartments of Pakistan: a review on occurrence and levels. Bulletin of environmental contamination and toxicology, 88(3), 303-310.

30. Van Emon, J. M., Chuang, J. C., Bronshtein, A., \& Altstein, M. (2013). Determination of polychlorinated biphenyls in soil and sediment by selective pressurized liquid extraction with immunochemical detection. Science of the total environment, 463, 326-333.

31. USA. (2002). Environmental protection Agency (EPA) Guildlinesand standards for Environmental Pollution Control 2002\&2007

32. Clarke, B. O., Porter, N. A., Marriott, P. J., \& Blackbeard, J. R. (2010). Investigating the levels and trends of organochlorine pesticides and polychlorinated biphenyl in sewage sludge. Environment International, 36(4), 323-329.

33. Dymkowska-Malesa, M., Plawgo, A., \& Walczak, Z. (2012). Levels of Polychlorinated Biphenyls (PCB) in Fish from the Lakes of the Warmia and Mazury Region. Journal of Environmental Science and Engineering. A, 1(2A).

34. Centre For Disease Prevention And Control, USA (CDC,2005) https://www.cdc.gov/mmwr/index2005.htm

35. Agency for Toxic Substances and Diseases Registry (ATSDR) US Department of Human Services: Toxicological Profile of alpha, beta, delta and gamma Hexachloro cyclohexane August 2005 http://www.sdr.cdc.gov/toxprofiles/tp43.pdf

36. Rogan, W.J., Chen. A. (2005). " Health risks and benefits of bis(4-chlorophenyl II trichloroethane (DDT).lancet 366(9487)

37. Eskenazi, B., Chevrier, J., Rosas, L. G., Anderson, H. A., Bornman, M. S., Bouwman, H., \& Leipzig, F. (2009). The Pine River statement: human health consequences of DDT use. Environmental health perspectives, 117(9), 1359-1367.

38. NIEHS. (2007). Endocrine Distruptors, National Institute of Environmental Health Sciences

39. Weber, R., Gaus, C., Tysklind, M., Johnston, P., Forter, M., Hollert, H., \& Moccarelli, P. (2008). Dioxin-and POP-contaminated sitescontemporary and future relevance and challenges. Environmental Science and Pollution Research, 15(5), 363.

40. Metcalf, R. L. (2000). Insect control. Ullmann's Encyclopedia of Industrial Chemistry.

41. Vos, J. G., Dybing, E., Greim, H. A., Ladefoged, O., Lambré, C., Tarazona, J. V., \& Vethaak, A. D. (2000). Health effects of endocrine-disrupting chemicals on wildlife, with special reference to the European situation. Critical reviews in toxicology, 30(1), 71-133.

42. Harley, K. G., Marks, A. R., Chevrier, J., Bradman, A., Sjödin, A., \& Eskenazi, B. (2010). PBDE concentrations in women's serum and 
fecundability. Environmental

health perspectives, 118(5), 699-704.

43. US Department of Health and Human Services. (1999). Agency for Toxic Substances and Disease Registry-ATSDR.

44. World Health Organization. (2010). The WHO recommended classification of pesticides by hazard and guidelines to classification 2009. World Health Organization.

45. US Department of Health and Human Services. (1999). Agency for Toxic Substances and Disease Registry-ATSDR.

46. Stein, C. R., Savitz, D. A., \& Dougan, M. (2009). Serum levels of perfluorooctanoic acid and perfluorooctane sulfonate and pregnancy outcome. American journal of epidemiology, 170(7), 837-846.

47. Gao, Y., Zhang, H., Zou, L., Wu, P., Yu, Z., Lu, X., \& Chen, J. (2016). Quantification of shortchain chlorinated paraffins by deuterodechlorination combined with gas chromatography-mass spectrometry. Environmental science \& technology, 50(7), 3746-3753.

48. Saiyed, H., Dewan, A., Bhatnagar, V., Shenoy, U., Shenoy, R., Rajmohan, H., ... \& Lakkad, B. (2003). Effect of endosulfan on male reproductive development. Environmental Health
49. Herbstman, J. B., Sjödin, A., Kurzon, M. A. T. T. H. E. W., Lederman, S. A., Jones, R. S., Rauh, V. I. R. G. I. N. I. A., ... \& Perera, F. (2015). Prenatal exposure to PBDEs and neurodevelopment. Everyday Environmental Toxins: Children's Exposure Risks, 223.

50. Stapleton, H. M., Klosterhaus, S., Keller, A., Ferguson, P. L., van Bergen, S., Cooper, E., ... \& Blum, A. (2011). Identification of flame retardants in polyurethane foam collected from baby products. Environmental science \& technology, 45(12), 5323-5331.

51. Bailey, R. E. (2007). Pentachlorobenzene-Sources, environmental fate and risk characterization. Science Dossier, 11th publication series.

52. Giesy, J. P., \& Kannan, K. (2002). Perfluorochemical surfactants in the environment, Envi-ron. Sci. Technol, 36.

53. Soto, A. M., Chung, K. L., \& Sonnenschein, C. (1994). The pesticides endosulfan, toxaphene, and dieldrin have estrogenic effects on human estrogensensitive cells. Environmental health perspectives, 102(4), 380-383.

54. Rahman, F., Langford, K. H., Scrimshaw, M. D., \& Lester, J. N. (2001). Polybrominated diphenyl ether (PBDE) flame retardants. Science of the Total Environment, 275(1-3), 1-17. 